\title{
Shoot tip and cotyledon explants of Eucalyptus saligna Sm. cultivated on different kanamycin levels
}

\author{
André Luís Lopes da Silva ${ }^{1 *}$, Yohana de Oliveira ${ }^{2}$, Jefferson da Luz Costa ${ }^{1}$, Elisângela \\ Masetto $^{2}$, Clarissa de Souza Mudry ${ }^{2}$, Eduardo Andrea Lemus Erasmo ${ }^{3}$ and Gessiel Newton \\ Scheidt $^{3}$
}

${ }^{1}$ Departamento de Engenharia de Bioprocessos e Biotecnologia; Universidade Federal do Paraná; 81531-970; Curitiba - PR - Brasil. ${ }^{2}$ Departamento de Fitotecnia e Fitosanidade; Universidade Federal do Paraná; 80035-050; Curitiba - PR - Brasil. ${ }^{3}$ Departamento de Ciências Agrárias e Tecnológicas; Universidade Federal do Tocantins; 77402-970; Gurupi-TO-Brasil.

\begin{abstract}
An efficient selective agent helps to obtain transgenic plants; the most used selective agent for genetic transformation of Eucalypt is kanamycin. The aim of this research was to determine ideal dose of kanamycin in shoot tip and cotyledon explants of E. saligna for use as selective agent in genetic transformation. Two experiments were carried out, first in order to test effects of the kanamycin in cotyledons and second, in order to test effects of the kanamycin in shoot tip. In the cotyledons experiment were tested 0, 12.5, 25, 37.5 and 50 mg. L $^{-1}$ kanamycin on a callus formation medium and for shoot tip were tested 50, 75, 100, 125 and 150 mg.L kanamycin on a multiplication medium. Cotyledons can be selected more quickly than shoot tip, moreover needs lower kanamycin levels than shoot tip, what results more speed and economy during genetic transformation process. It is probable that levels lower than $12.5 \mathrm{mg} . \mathrm{L}^{-1}$ kanamycin must be ideal for the cotyledons selection and $50 \mathrm{mg} . \mathrm{L}^{-1} \mathrm{kanamycin} \mathrm{for}$ shoot tip.
\end{abstract}

Key words: Eucalypt, woody plant, genetic transformation

\section{INTRODUCTION}

Eucalypt is the most cultivated woody species around the world and Brazil is the second larger producer, several species are cultivated to wood, cellulose and paper (Alfenas et al., 2004). Eucalyptus saligna is relatively adapted in all Brazilian territory (Ferraz and Coutinho, 1984), however, this species is no much tolerant to cold (Le Roux and Van Staden, 1991), and it is susceptible to frost (Ferraz and Coutinho, 1984). The largest restriction to eucalypt culture in the south of Brazil is due to cold and to the incidence of frosts (Silva et al., 2009). Frost is too severe that eucalypt trees show since burned tip until dead of the aerial part (Selle and Vuaden, 2008).

Genetic transformation can overcome susceptibility to biotic and abiotic stresses. However, for an efficient protocol of genetic transformation, several factors are involved. One of them is use of an efficient selective agent, which allows in vitro regeneration of transgenic plants and eliminating non transgenic plants, this is possible using a tolerance gene to the selective agent, such as NPTII gene (i.e. it codes an enzyme called neomycin phosphotransferase II) that inactivate antibiotics of aminoglycosides class (e.g. gentamicin, kanamycin, neomycin, and others). Nevertheless, in Eucalyptus the kanamycin effects is very variable and it is dependent of the species and clone (Gonzales et al., 2001).

The aim of this research was to determine ideal dose of kanamycin in shoot tip and cotyledon explants of E. saligna for use as selective agent in genetic transformation.

\section{MATERIAL AND METHODS Explants source}

In order to test effects of the kanamycin in cotyledons, these explants were obtained through in vitro germination. Seeds of Eucalyptus saligna

Author for correspondence: clonageinvitro@yahoo.com.br 
Sm. were disinfected with ethanol $70 \%$ during 3 min., and after in $\mathrm{NaOCl} 6 \%$ (with 5 drops Tween $20^{\circledR}$ per $100 \mathrm{~mL}$ ) for $30 \mathrm{~min}$., and after washed three times with distilled and autoclavated water. Seeds were sowed on MS half strength medium (Murashige and Skoog, 1962) with 20 g.L $\mathrm{L}^{-1}$ sucrose and solidified with 7 g. $\mathrm{L}^{-1}$ agar.

In order to test effects of the kanamycin in shoot tip, shoot clusters of E. saligna were obtained through indirect organogenesis (Dibax, 2007), these clusters were donor of shoot tip; these clusters were multiplicated on $\mathrm{M}$ medium, which consisted of MS medium, 30 g. $\mathrm{L}^{-1}$ sucrose, 1.11 $\mu \mathrm{M}$ BAP (6-benzylaminopurine) and solidified with $7 \mathrm{~g} . \mathrm{L}^{-1}$ agar.

Tolerance to kanamycin in cotyledon explants Cotyledons from the seedlings (15 days old) were excised and cultivated on MS medium supplemented with $2.7 \quad \mu \mathrm{M} \quad$ NAA (naphthaleneacetic acid) and $4.4 \mu \mathrm{M}$ BAP, 30 g.L. $\mathrm{L}^{-1}$ sucrose and solidified with 7 g.L. $\mathrm{L}^{-1}$ agar. The treatments were: $0,12.5,25,37.5$ and $50 \mathrm{mg} . \mathrm{L}^{-1}$ kanamycin. Explants were maintained in dark until 15 days, after they were placed at $5 \mu \mathrm{M} \mathrm{m}^{-2} \mathrm{~s}^{-1}$. Explants were subcultured each 28 days. Callus formation percentage and survival percentage were evaluated at 28, 56 and 84 days of in vitro culture.

\section{Tolerance to kanamycin in shoot tip}

Shoot tip (5 mm heigth and without lateral shoots) were removed of shoot clusters of E. saligna and cultivated on $\mathrm{M}$ medium supplemented with different kanamycin levels $(50,75,100,125$ and $\left.150 \mathrm{mg} . \mathrm{L}^{-1}\right)$. Explants were subcultured each 28 days for the same media. The shoot number and survival percentage were evaluated at $28,56,84$, 112,140 and 168 days of in vitro culture. The explants were kept in a growth room with a light intensity of $0.18 \mu \mathrm{M} \mathrm{m} \mathrm{m}^{-2} \mathrm{~s}^{-1}$ with a $16 \mathrm{~h}$ photoperiod.

\section{Culture conditions and statistical analysis}

Kanamycin was microfiltered and supplemented to the media after autoclaving. All media had their $\mathrm{pH}$ adjusted to 5.8 and were autoclaved at $1 \mathrm{~atm}$ and $121{ }^{\circ} \mathrm{C}$ for $20 \mathrm{~min}$. The cultures were kept at $25 \pm 2{ }^{\circ} \mathrm{C}$. The experimental design was a complete randomized with five replicates of five explants. The data was submitted in a normality analysis for the Lilliefors's test and, analysis of variance followed by regression analysis at the level of 5\% of error. All analysis were done following the procedures of the software GENES (Cruz, 2001). Variables from counting were transformed to $\sqrt{x+0.5}$ and variables from percentage were transformed to $\arcsin \sqrt{x / 100}$.

\section{RESULTS AND DISCUSSION}

Tolerance to kanamycin in cotyledon explants

During all experimental period the callus formation occurred only in the absence of kanamycin, and all explants alive, formed callus (ca. 80\%). Similar results were found in E. saligna which $85 \%$ of explants have formed callus (Dibax, 2007). After 30 days of in vitro culture, survival of cotyledons varying from 70 to $80 \%$. Similar results were observed in cotyledons of Eucalyptus grandis, which levels of kanamycin, 50 and 100 mg. $\mathrm{L}^{-1}$ induced ca. $90 \%$ of survival after 30 days of culture (González, 2002).

In Eucalyptus globulus, level of $100 \mathrm{mg} . \mathrm{L}^{-1}$ kanamycin allows an efficient selection for transformed callus (Serrano et al., 1996), nevertheless, in Eucalyptus camaldulensis, level of $20 \mathrm{mg} . \mathrm{L}^{-1}$ kanamycin inhibits significativaly callus formation (Ho et al., 1998).

Callus formed shoots at third month, ca. $15 \%$. However, just $65 \%$ of callus was alive at the end of 84 days; they have a browned appearance, probably for oxidation occurrence. In spite of the low light intensity $\left(5 \mu \mathrm{M} \mathrm{m}^{-2} \mathrm{~s}^{-1}\right)$ oxidation occurred, however it is probable that, in case of the light intensity more elevate than it, these explants possibly were dead before third month. Surviving explants were drastic affected at the end of third month due to oxidation.

The levels from 12.5 to $50 \mathrm{mg} . \mathrm{L}^{-1}$ were sufficiently to kill all explants in a period of three months (Fig. 1).

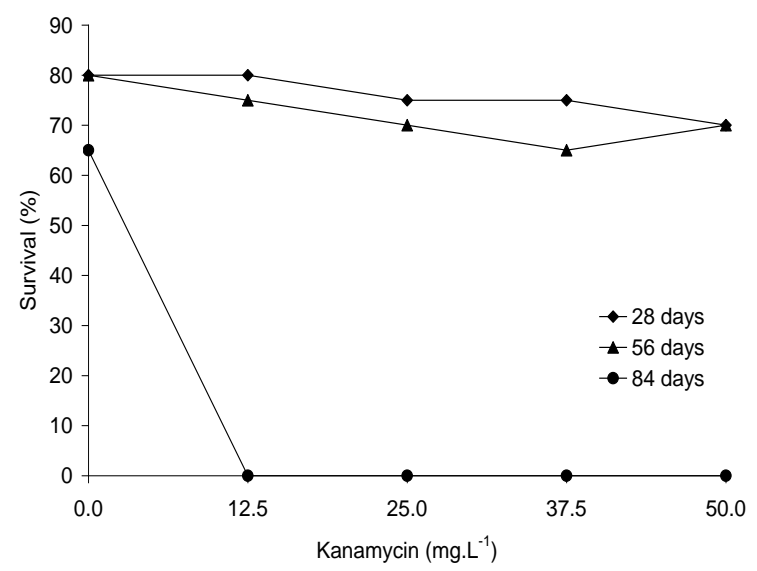


Figure 1- Survival of cotyledons of Eucalyptus saligna cultivated at different levels of kanamycin after 28, 56 and 84 days of in vitro culture.

These results have suggested that lower levels of kanamycin must be used as selection agent for genetic transformation of cotyledons of E. saligna. These levels are below of the kanamycin level used in a genetic transformation protocol established to E. saligna, which is $50 \mathrm{mg} \cdot \mathrm{L}^{-1}$; however this protocol was developed for leaf explants (Dibax, 2007).

\section{Tolerance to kanamycin in shoot tip}

The presence of kanamycin on media culture have affected rate proliferation, each 28 days we have observed decreases in shoot number of shoot tip, these data followed a negative linear effect (Figure 2).
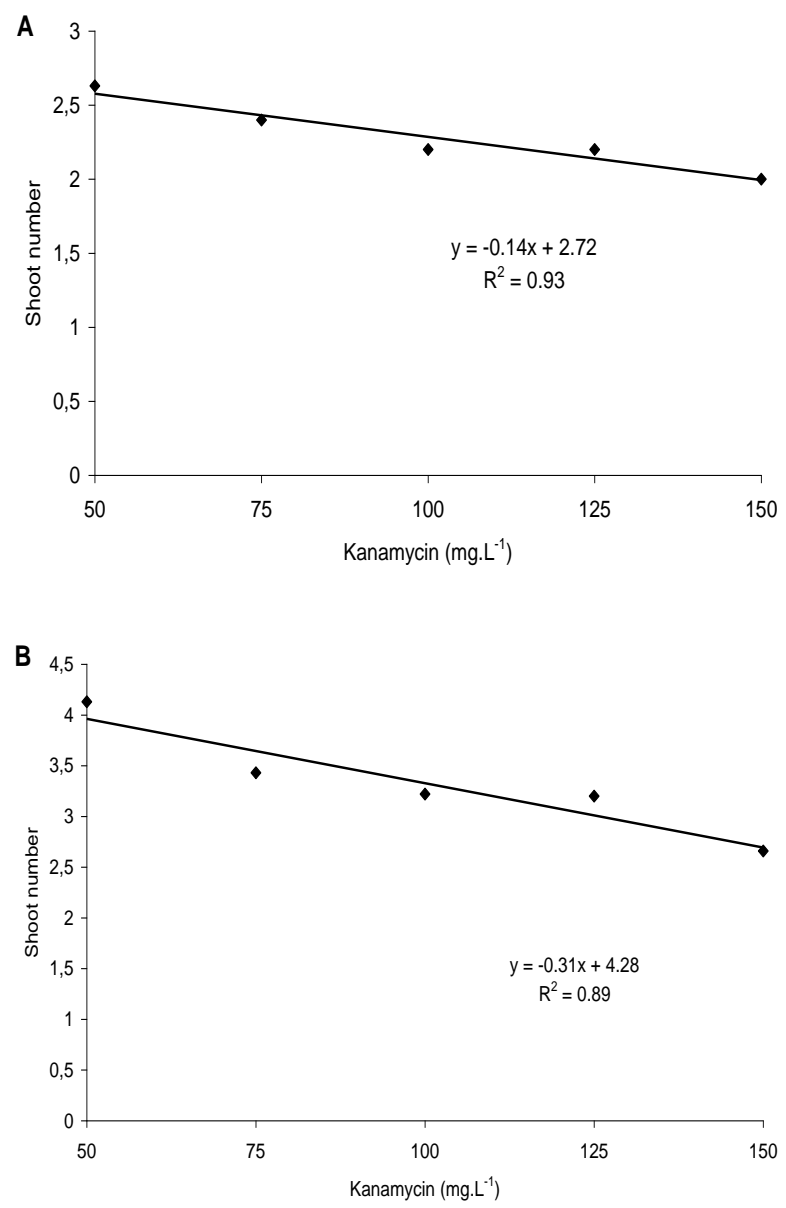
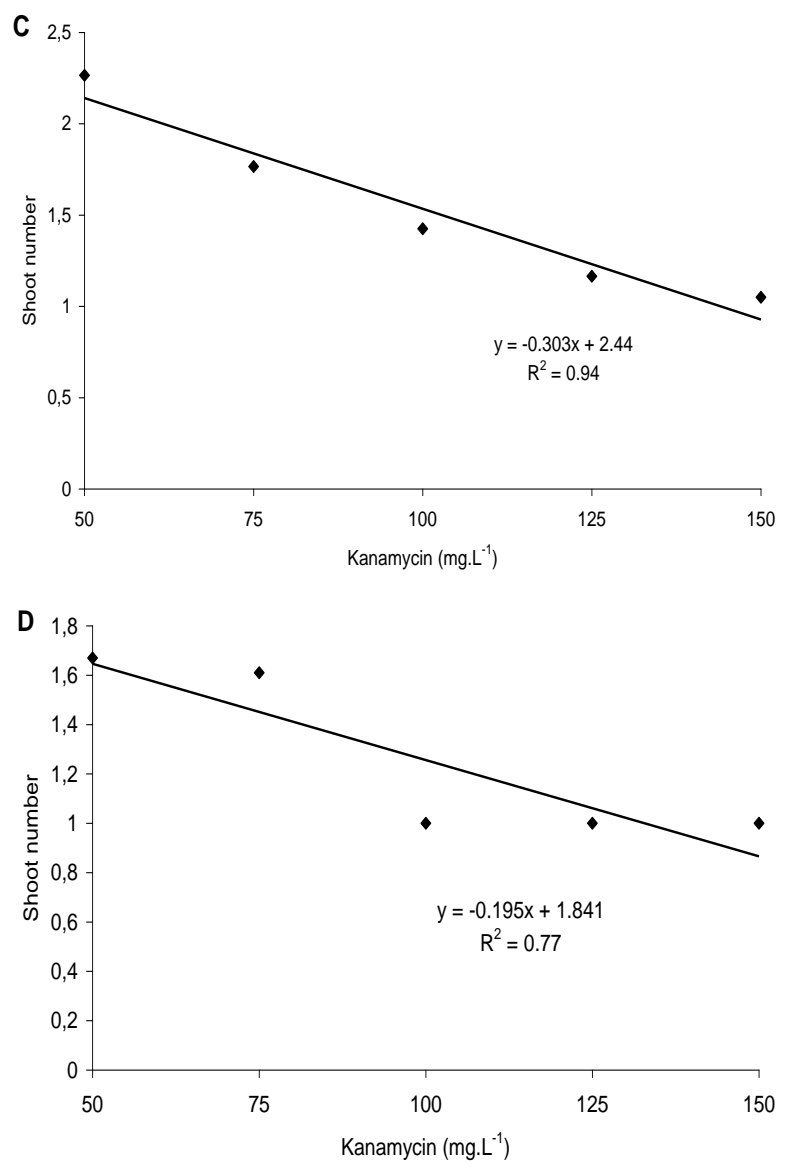

Figure 2- Effect of kanamycin in shoot number of shoot tip of Eucalyptus saligna after (A) 28, (B) 56, (C) 84 and (D) 112 days of in vitro culture.

In the first and second month, shoot tip have multiplicated in presence of kanamycin, in all levels (50-150 mg.L $\left.{ }^{-1}\right)$, however at the third month, shoots begin to die (Figure 2C). At the fourth month, shoot tip had just one shoot cultivated on levels of 100 to $150 \mathrm{mg} . \mathrm{L}^{-1}$ kanamycin, (Figure 2D).

Survival percentage of shoot tip followed a negative quadratic effect. Shoot tip begin to die at the third month, survival rate at $50 \mathrm{mg} . \mathrm{L}^{-1}$ stayed $100 \%$, while higher levels promoted explants dead (Figure 3A). 

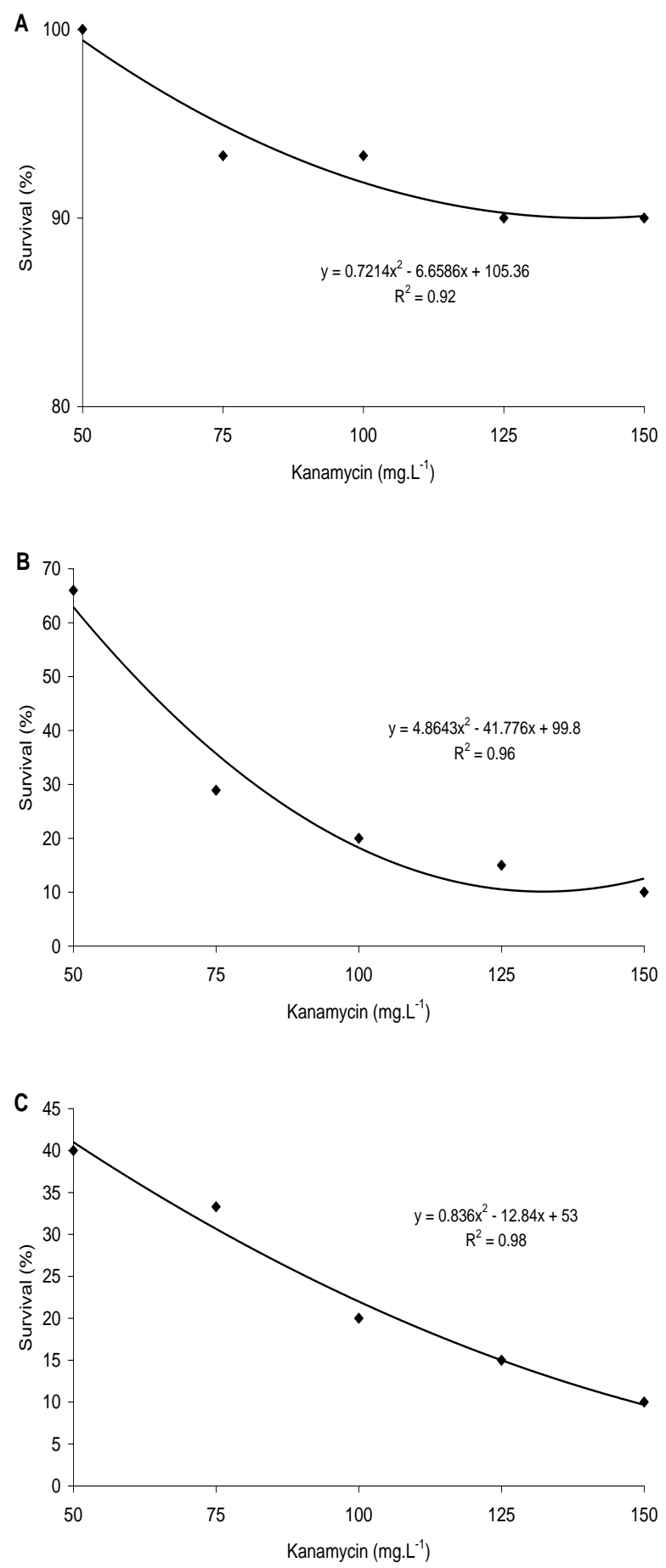

Figure 3- Percentage of survival of shoot tip of Eucalyptus saligna cultured at different levels of kanamycin after (A) 84, (B) 112 and (C) 140 days of in vitro culture.

During fourth month survival rate have varied from 67 to $14 \%$, and during fifth month this rate varied from 42 to $14 \%$ (Figure 3B-C). At the next month, all explants are died. Different results were found in E. camaldulensis, which $9 \mathrm{mg} . \mathrm{L}^{-1}$ kanamycin inhibit shoot regeneration (Mullins et al., 1997). E. saligna plantlets cultivated at 100 mg. $\mathrm{L}^{-1}$ kanamycin showed $3.9 \%$ survival rate after 60 days of culture (Andrade, 2001).

\section{CONCLUSIONS}

Cotyledons can be selected more quickly than shoot tip, moreover needs lower kanamycin levels than shoot tip, what results more speed and economy during genetic transformation process. It is probable that levels lower than $12.5 \mathrm{mg} . \mathrm{L}^{-1}$ kanamycin must be ideal for the cotyledons selection and $50 \mathrm{mg} . \mathrm{L}^{-1}$ kanamycin for shoot tip.

\section{RESUMO}

Um agente seletivo eficiente é determinante no processo de obtenção de plantas transgênicas; o agente seletivo mais usado para transformação genética de eucalipto é a canamicina. O objetivo desse trabalho foi determinar as concentrações ideias de canamicina em cotilédones e em ápices caulinares de Eucalyptus saligna para uso como agente seletivo para transformação genética. Dois experimentos foram conduzidos, um para testar os efeitos da canamicina nos cotilédones e o outro para testar os efeitos da canamicina nos ápices caulinares. No experimento com cotilédones foram testadas as seguintes concentrações: 0, 12.5, 25, 37.5 and $50 \mathrm{mg} . \mathrm{L}^{-1}$ de canamicina em meio para formação de calos e no experimento de ápices caulinares foram testadas as concentrações de 50,75 , 100, 125 e 150 mg. $\mathrm{L}^{-1}$ de canamicina em meio de multiplicação. Cotilédones podem ser selecionados mais rapidamente do que os ápices caulinares, além disso necessitam de menores concentrações de canamicina, o que resultaria maior velocidade e economia durante $o$ processo de transformação genética. É provável que níveis inferiores que 12,5 mg. $L^{-1}$ de canamicina sejam ideais para a seleção de cotilédones. Para a seleção de ápices caulinares podem ser usados $50 \mathrm{mg} . \mathrm{L}^{-1}$ de canamicina.

Palavras-chave: Eucalipto, espécie lenhosa, transformação genética

\section{REFERENCES}

Alfenas, A. C.; Zauza, E. A. V.; Mafia, R. G.; Assis, T. F. (2004), Clonagem e doenças do Eucalipto. Viçosa: UFV, Imprensa Universitária. p. 442.

Andrade, A. Avaliação de parâmetros que influenciam a transformação genética do Eucalyptus grandis via Agrobacterium. Dissertação (Mestrado em Agronomia) Universidade de São Paulo, 2001. 
Cruz, C. D. (2001), Programa Genes: versão Windows; aplicativo computacional em genética e estatística. Viçosa: UFV, Imprensa Universitária. p. 648.

Dibax, R. Transformação e expressão do gene PC5SF129-A em Eucalytus saligna. Tese (Doutorado em Agronomia) - Universidade Federal do Paraná, 2007.

Ferraz, E. S. B. and Coutinho, A. R. (1984), Efeitos da geada na madeira de Eucalyptus saligna. IPEF, 28, 57-62.

Gonzales, E. R.; Andrade, A.; Bertolo, A. L.; Lacerda, G. C.; Carneiro, R. T.; Prado Defávari, V. A.; Labate, C. A. The efficiency of aminoglycoside antibiotics in the regeneration ans selection of Eucalyptus spp. (2001), In: International Conference Eucalyptus in the Mediterranean Basin: Perspectives and New Utilizations. Taormina, 1999. Anais. Taormina: Centro Promozione Publicità Press. p. 45-48.

González, E. R. Transformação genética de Eucalyptus grandis e do híbrido E. grandis x $E$. urophyla via Agrobacterium. Tese (Doutorado em Agronomia) - Universidade de São Paulo, 2002.

Ho, C. K.; Chang, S. H.; Tsay, J. Y.; Tsai, C. J.; Chiang, V. L.; Chen, Z. Z. (1998), Agrobacterium tumefaciens mediated transformation of Eucalyptus camaldulensis and production of transgenic plants. Plant Cell Reports, 17, 675-680.

Le Roux, J. J. and Van Staden, J. (1991), Micropropagation of Eucalyptus species. Hortscience, 26, 199-200.

Mullins, K. V.; Llewellyn, D. J.; Hartney, V. J.; Strauss, S.; Dennis, E. S. (1997), Regeneration and transformation of Eucalyptus camaldulensis. Plant Cell Reports, 16, 787-791.

Murashige, T. and Skoog, F. (1962), Revised medium for rapid growth and bioassays with tobacco tissue culture. Physiologia Plantarum, 15, 473-497.

Selle, G. L. and Vuaden, E. (2008), Efeitos da geada sobre plantações de Eucalypus grandis. Caderno de Pesquisa Série Biologia, 20, 36-44.
Serrano, L.; Rochange, F.; Semblat, J. P.; Marque, C.; Teulières, C.; Boudet, A-M. (1996), Genetic transformation of Eucalyptus globulus through biolistics: complementary development of procedures for organogenesis from zygotic embryos and stable transformation of corresponding proliferation tissue. Journal of Experimental Botany, 47, 285-290.

Silva, A. L. L.; Oliveira, Y.; Alcantara, G. B.; Santos, M.; Quoirin, M. (2009), Tolerância ao resfriamento e congelamento de folhas de eucalipto. Biociências, 17, 86-90. 